\title{
Agenda Setting Theory Pencalonan Walikota Jambi di Media Seru Jambi.com
}

\author{
Sobirin, Muhaimin, M. Junaidi, Dian Mursyidah \\ UIN Sulthan Thaha Saifuddin Jambi \\ Email: dianmursyidah@uinjambi.ac.id
}

\begin{abstract}
Abstrak: Penelitian ini dilatarabelakangi oleh realitas pemberitaan suatu media dalam mengkontruksi figur politik kandidat Walikota yang berkampanye melalui media tersebut. Melalui teori agenda setting media, penulis mengkaji media SeruJambi.com dalam memberitakan Syarif Fasha sebagai salah satu calon kandidat Walikota Jambi pada tahun 2018. Analisa melalui tiga hal, yaitu: pembingkaian pesan, pengunaan kata-kata dan objektivitas. Metode penelitian yang digunakan adalah kualitatif interpretatif dengan menekankan pada sumber tertulis berupa isi dokumentasi berita-berita Syarif Fasha pada media online SeruJambi.com. Hasil penelitian menemukan adanya ketidakberimbangan Seru Jambi.com dalam mengkonstruksi berita Syarif Fasha sebagai salah satu kandidat Walikota Jambi 2018. Terdapat strategi pembingkaian pesan dalam memberitakan kehidupan sehari-hari kandidat. Penggunaan kata-kata dengan strategi penyederhanaan dari bahasa ilmiah kedalam bahasa sehari-hari, pengulangan kata sebagai penunjuk gagasan inti dari berita, sinonim (kesamaan kata) dengan penulisan kata yang berbeda untuk mencegah kebosanan. Kesamaan topik untuk memperjelas suatu kalimat sebelumnya, sebagai strategi pembingkaian untuk menonjolkan gagasan inti berita.
\end{abstract}

Kata-kata kunci: bingkai berita, Syarif Fasha, Seru Jambi.com

\section{A. Pendahuluan}

Sistem pemilihan umum diartikan sebagai satu kumpulan metode atau cara warga masyarakat memilih para wakil mereka (Lijphart,1995). Manakala lembaga perwakilan rakyat, apakah itu DPR ataupun DPRD dipilih, maka sistem pemilihan mentransfer jumlah suara kedalam sebuah kursi. Sementara itu, pemilihan presiden, gubernur, dan bupati, yang merupakan representasi tunggal dalam 
sistem pemilihan, dasar jumlah suara yang diperoleh menentukan siapa yang menang dan siapa yang kalah. Dengan melihat kenyataan seperti itu, maka betapa pentingnya sistem pemilihan dalam sebuah demokrasi. ${ }^{1}$

Dewasa ini pemilihan kepala daerah menjadi momentum politik yang selalu menarik perhatian publik, bukan hanya saat pemilihan itu berlangsung satu atau dua tahun sebelum komisi pemilihan kepala daerah (KPUD) menetapkan hari pemilihan, masyarakat sudah ramai memperbincangkan dan sekaligus memprediksi bakal calon pemimipin di daerahnya, fenomena yang lazim dijumpai disetiap momen pilkada misalnya komunikasi orang-orang di warung kopi, percakapan para user di jejaringan sosial dan media online serta perbincangan masyarakat pada umumnya, saling beradu argumen mempertahankan reputasi dan poplaritas kandidatnya. ${ }^{2}$

Disadari atau tidak masyarakat tergerak mengikuti arus informasi yang diterimanya baik melalui kampanye tim relawan atau tim pemenangan, pemanfaatan lembaga survey pengarusutamaan wacana popularitasan elektabilitas kandidat, terutama pemamfaatan media lokal dengan seluruh jaringan nya. Dalam konteks ini pengemasan "isu politik" melalui media dianggap penting untuk mengiring opini publik tentang bentukan citra kandidat kepala daerah maupun incumbent yang bergantung dipilkada. Secara objektif para wartawan dan media dalam mengkonstruksi berita politik berpedoman pada regulasi pers dan dalam berbagai normatif didalam dunia jurnalistik, namun demikian, subjektivitas wartawan adalah suatu keniscayaan jika ditelisik adanya kepentingan ekonomi politik media yang bersangkutan.

Media adalah tempat di mana khalayak memperoleh informasi mengenai realitas politik dan sosial yang terjadi di sekitar mereka.Karena itu, bagaimana individu menafsirkan peristiwa tersebut. Dengan kata lain, frame yang disajikan

\footnotetext{
${ }^{1}$ Afan Gaffar,Politik Indonesia , Transisi Menuju Demokrasi, (Yogyakarta2005), 255.

${ }^{2}$ Boby Tridona, Diakses melalui alamat,http://digilib.unila.ac.id
} 
oleh media ketika memaknai realitas mempengaruhi bagaimana khalayak menafsirkan peristiwa. ${ }^{3}$

Kajian komunikasi politik pada awalnya berakar pada ilmu politik, meskipun penamaan lebih banyak dikenal dengan istilah propaganda ini dimulai pada tahun 1922 dengan penelitian dari Ferdian tonnies Walter Lippmann yang meneliti tentang opini public pada masyarakat, kemudian dilanjutkan oleh Bagehot, maine, Byrce, dan Graha Wallas di Inggris yang menelaah peranan pers dan pembentukan opini publik. ${ }^{4}$

Pada tahun 2018 mendatang kota jambi akan melaksanakan pemilihan kepala daerah (PILKADA), pilkada serentak menurut UU 8/2015, pelaksanaan pemilihan gubernur,bupati, dan walikotadi lakukan setiap lima tahun sekali secara serentak. Sesuai undang-undang no 8 tahun 2015, pilkada serentak dilaksanakan secara bertahap tahap pertama pada tanggal 9 Desember 2015, tahap kedua pada bulan pebruari 2017, tahap ketiga pada bulan juni 2018, tahap keempat pada tahun 2020, tahap kelima, pada tahun 2022.

Syarif Fasha adalah salahsatu calon walikota bagaimanakah pengaruh media terhadap pencalonan walikota jambi Syarif Fasha dalam pemberitaan pada media Online Seru Jambi.com sehingga memunculkan opini publik.media mempunyai kemampuan untuk menyeleksi dan mengarahkan perhatian masyarakat pada gagasan atau peristiwa tertentu,media mengatakan apa yang penting dan apa yang tidak penting, mediapun mengatur apa yang kita lihat, tokoh siapa yang harus kita dukung. ${ }^{5}$

Penonjolan-penonjolan berita lebih di tekankan pada suatu media,untuk menarik khalayak,seperti jika media massa selalu mengarahkan untuk mendukung tokoh tertentu,bukan tidak mustahil kahalayak akan ikut terpengaruh mendukung tokoh tertentu yang didukung media massa tersebut.

${ }^{3}$ Eriyanto, Analisis Framing,konstruksi, ideology, dan politik media,(Yogyakarta: LKIS Yogyakarta, 2002), 177.

${ }^{4}$ Cangara, Hafied, Komunikasi politik: Konsep,teori, dan strategi,(Jakarta: Rajawali pers, 2019), 32 .

5 Nurudin, Pengantar komunikasi massa, (Jakarta: Rajagrafindo persada, 2004), 196. 
Daya tarik, Komunikator akan berhasil dalam komunikasi, akan mampu mengubah sikap, opini, dan perilaku komunikan melalui mekanisme daya tarik jika pihak komunikan merasa bahwa komunikator ikut serta dengannya. Dengan kata lain, komunikan merasa ada kesamaan antara komunikator dengannya sehingga komunikan bersedia taat pada isi pesan yang dilancarkan oleh komunikator. ${ }^{6}$

Selain harus memeliki ketepatan (akurasi) dan kecepatan dalam bekerja,wartawan dituntut untuk tetap objektif dalam menulis. Dengan sikap objektif nya,berita yang akan ia buatpun akan objektif, berita yang dibuat itu selaras dengan kenyataan tidak berat sebelah, bebas dari prasangka lawan dari objektif adalah subjektif, yaitu sikap yang diwarnai dengan prasangka pribadi memandang ada beberapa karya jurnalistik yang lebih persuasive, artinya ada sikap subjektif didalamnya, dan objektivitasnya kendur, misalnya dalam tulisan editorial atau komentar, sebuah depth-riporting tidak memihak dalam menulis berita. $^{7}$

Media online merupakan salah satu media yang tepat dipilih untuk mencari eksistensi sutu calon kandidat, karena dewasa ini masyarakat mengiginkan suatu berita lebih ringkas mudah di akses kapan saja dan dimana saja asalkan terhubung dengan internet, pada dasarnya manusia sekarang dituntut untuk lebih cepat dalam menerima informasi secara instan dan mudah dimegerti apa inti berita atau informasi yang disampaikan suatu media, seperti Seru Jambi.com yang banyak memuat berita kampanye calon walikota Jambi syarif fasha.

Kampanye merupakan aktivitas komunikasi yang ditujukan untuk mempengaruhi orang lain agar ia memiliki wawasan,sikap dan perilaku sesuai dengan kehendak dan keinginan penyebar atau pemberi informasi. Dalam konteks komunikasi politik.kampanye dimasudkan untuk memobilisasi dukungan

${ }^{6}$ Onong Uchjana Effendi, Ilmu Komunikasi Teori dan Praktek, (Bandung: Remaja rosda karya, 2013), 38

7 Hikmat kusumaningrat,Jurnalistik Teori dan paraktik,Bandung:Remaja Rosda Karya). 40252.54-55 
terhadap suatu halatau kandidat, kampanye juga suatu upaya persuasif untuk mengajak orang lain yang belum sepaham atau belum yakin padaide-ide yang ditawarkan. Oleh sebab itu media mengemas pemberitaan kampanye sebaik mungkin sehingga ide-ide yang dilontarkan bisa dimasukkan kedalam pikiran pembaca atau khalayak luas yang diharapkan dukungannya.

Kampanye politik adalah penciptaan, penciptaan ulang, dan pengalihan lambang signifikan secara sinambung melalui komunikasi Kampanye menggabungkan partisipasi aktif yang melakukan kampanye dari pemberian suara. ${ }^{8}$

Efek dari pemberitaan pasti akan terjadi, seberapa kuat kah pengaruh media massa terhadap publik?, Bagaimana agenda media terhadap khalayak?, bagaimana pembingkaian berita Seru Jambi.com agar menarik publik?, bagaimana pengunaan kata-kata serta objektivitas Seru Jambi.com dalam mempengaruhi khalayak?, tentu mempunyai efek yang pastinya akan berpengaruh terhadap khalayak, baik efek primer maupun efek skunder.

Berdasarkan permasalahan diatas, maka penelitian ini akan melihat bagaimana pembingkaian pesan SeruJambi.com terhadap berita-berita Syarif Fasha, bagaimana penggunaan kata-kata dalam pembingkaian pesan media online SeruJambi.com terhadap berita-berita Syarif Fasha, dan bagaimana objektivitas media online SeruJambi.com terhadap pembingkaian pesan beritaberita Syarif Fasha.

Pada penelitian ini penulis mengunakan metode kualitatif interpretatif, dengan pendekatan analisis isi berita. Subjek dari penelitian ini adalah SeruJambi.Com, sementara yang menjadi objek penelitiannya adalah berita Syarif Fasha dalam SeruJambi.com yang diambil pada bulan November 2017 dari tanggal 03 sampai tanggal 28 November.

8 Dan Nimmo,Komunikasi politik khalayak dan efek, (Bandung: Remaja Rosdakarya), 2010,172 . 


\section{B. Agenda Setting Theory}

Maxwell McCombs dan Donald L. Shaw adalah orang yang pertama kali memperkenalkan teori agenda setting ini, teori ini muncul sekitar tahun 1973 dengan publikasi pertamanya berjudul "The Agenda Setting Function of The Mass Media" Public Opinion Quarterly No. 37. ${ }^{9}$

Ketika diadakan penelitian tentang pemilihan presiden Amerika serikat pada tahun 1968 ditemukan hubungan yang tinggi antara penekanan berita dengan bagaimana berita itu dinilai tingkatannya oleh pemilih. Meningkatnya nilai penting suatu topik berita pada media massa menyebabkan meningkatnya nilai penting topik tersebut bagi khalayaknya.

Secara singkat teori penyusunan agenda setting ini mengatakan media (khususnya media berita) tidak selalu berhasil memberitahu apa yang kita pikir, tetapi media tersebut benar-benar berhasil memberitahu kita berpikir tentang apa. Media massa selalu mengarahkan kita pada apa yang harus kita lakukan. Media memberikan agenda-agenda melaui pemberitaannya, sedangkan masyarakat akat ikut mengikutinya. Menurut asumsi teori ini mempunyai kemampuan untuk menyeleksi dan mengarahkan perhatian masyarakat pada gagasan atau peristiwa tertentu. Media mengatakan pada kita apa yang penting dan apa yang tidak penting. Media pun mengatur apa yang harus kita lihat, tokoh siapa yang harus kita dukung.

Mengikuti pendapat Chaffe dan berger ada beberapa catatan yang perlu dikemukakan untuk memperjelas teori ini.

a. Teori itu mempunyai kekuatan penjelas untuk menerangkan mengapa orangorang menggangap penting suatu isu.

b. Teori itu mempunyai kekuatan memprediksikan sebab memprediksikan bahwa jika orang-orang mengekspos pada suatu media yang sama, mereka akan merasa isu yang sama tersebut penting.

\footnotetext{
${ }^{9}$ Ibid, 195.
} 
c. Teori itu dibuktikan salah jika orang-orang tidak mengekspos media yang sama maka mereka tidak akan mempunyai kesamaan bahwa isu media itu penting.

Sementara itu, Stephen W. Litthelejohn pernah mengatakan, Agenda setting ini beropererasi dalam tiga sebagai berikut:

1. Agenda media itu sendiri harus diformat proses ini akan memunculkan masalah bagaimana agenda media itu terjadi pada waktu pertama kali.

2. Agenda media dalam banyak hal memengaruhi atau berinteraksi dengan agenda publik atau kepentingan isu tertentu bagi publik. Peryataan ini memunculkan pertayaan, seberapa besar kekuatan media mampu memegaruhi agenda publik dan bagaimana publik itu melakukannya.

3. Agenda publik memegaruhi atau berinteraksi kedalam agenda kebijakan. Agenda kebijakan adalah pembuatan kebijakan publik yang diangap penting bagi individu.

Agenda setting beroperasi dalam tiga bagian, yaitu:

a. Agenda Media. Agenda harus diformat, proses akan memunculkan masalah bagaimana agenda media ini terjadi pada waktu pertama kali dengan dimensi yang berkaitan, atara lain: visability (yakni jumlah dan tingkat menonjolnya berita), Audience selience (tingkat menonolnya bagi khlayak), Valence (velensi), yakni menyenangkan atau tidak menyenangkan cara pemberitaan bagi suatu peristiwa

b. Agenda khalayak. Agenda media dalam banyak hal memegaruhi atau berinteraksi dengan agenda publik atau isu tertentu bagi publik. Peryataan ini memunculkan peryataan,seberapa besar kekuatan media mampu mempengaruhi agenda publik dan bagaimana publik itu melakukannya. Dimensi yang berkaitan antara lain: Familiarity (keakraban), personal salience (penonjolan pribadi), Favorability (kesenangan).

c. Agenda kebijakan. Agenda publik memegaruhi atau berinteraksi kedalam agenda kebijakan. Agenda kebijakan adalah pembuatan kebijakan publik yang dianggap penting bagi individu. Dimensi yang berkaitan antara lain: support 
(dukungan), Likelihood of action (kemungkinan kegiatan), yakni kemungkinan pemerintah melaksanakan apa yang diharapkan, Freedom of action (kebebasan bertindak), yakni nilai kegiatan yang mungkin dilakukan pemerintah. ${ }^{10}$

\section{Sejarah Seru Jambi.com}

Seru Jambi merupakan koran lokal yang berada di kota jambi tapatnya kantor Seru Jambi terletak di Jaluko ( Jambi luar kota) yang beralamt di Jl. Lintas Jambi, Muaro Bulian KM 14 RT 01/01 Mendalo Indah Muaro Jambi. Awal berdirinya media online seru jambi.com tanggal 7 Juni 2017 diasosisi oleh empat orang yaitu ramunas, awin, ivan, dan hadi pembentukan seru jambi.com di latar belakangi oleh bisnis berdirinya seru jambi.com yaitu sama seperti media lain yaitu bisnis, media seru jambi merupakan perusahaan bisnis produk/porbis yang di jual yaitu berupa berita dalam konteks pengembangan bisnis, Seru Jambi.com berdiri sendiri tidak berinduk pada group media lain hanya ada Seru Jambi Group seperti, Seru Jambi koran, Seru Jambi percetakan.

Sejak terbitnya media online hampir seluruh media seperti koran lokal jambi memiliki media online yang di sajikan secara online seperti Jambi Update.com Jambi independent.com, MetroJambi.com dan yang lainya,pembaca hanya perlu menggunakan gadget ataupun komputer yang terhubung dengan internet untuk mengakses berita pada media online Seru Jambi.com melalaui situs web resmi Seru Jambi.com mengingat saat ini keberadaan koran sudah tidak bisa lagi di handalkan karena koran.

Tidak hanya media online dan koran saja, Seru Jambi juga memiliki koran digital pertama di kota Jambi dengan penyebaran melalui aplikasi WhatsApp, ini memudahkan masyarakat untuk memperoleh informasi secara mudah hanya membutuhkan jaringan internet dan aplikasi WhatsApp. dilihat sekarang hampir

10 Apriadi Tamburaka, Agenda Setting Media Massa, (Jakarta: Rajagrafindo Persada, 2012), 68-69. 
seluruh masyarakat memiliki gadget. Dengan begitu masyarakat yang memiliki gadged sudah bisa menerima informasi secara gratis tampa harus membeli koran lagi, karena berita yang diterima melalui aplikasi WhatsApp sudah berbentuk koran utuh.

\section{Pembingkaian Pesan dan Penggunaan Kata}

Susunan gramatikal di dalam ungkapan bahasa memang harus dipahami berkaitan dengan praktik penggunaannya dalam kompleksitas kehidupan seharihari manusia,tidak hanya memahami suatu bahasa melalui strukturalismenya saja, akan tetapi kita bisa memahami makna dalam suatu bahasa dalam suatu kalimat dengan makna dalam hidup. sehingga kita tidak hanya memandang bahasa dari logika saja atau logika matematis.

Berdasarkan hasil penelusuran data berita di Seru Jambi.com dalam berita politik ditemukan beberapa sampel berita yang secara spesifik mengangkat tema berita politik Syarif Fasha. Data berita Seru Jambi.com menunjukan beberapa kategori yaitu, yang pertama pencalonan Syarif Fasha sebagai walikota Jambi pada tahun 2018 mendatang, yang kedua berita kampanye poltik Syarif Fasha. Beberapa kategori berita tersebut kemudian di interpretasikan melalui analisis Agenda Setting dalam pembingkaian pesan sebagai berikut.

Judul Berita

1. "Fasha-Maulana Dapatkan Hati Hanura"

Dari hasil pengamatan penulis, bagaimana wartawan SeruJambi.com menggunakan kata dalam teks berita terdapat pembingkaian pesan untuk memaknai kehidupan sehari-hari dengan judul berita "Fasha-Maulana Dapatkan Hati Hanura" sebagai berikut:

Setelah diteliti Dalam berita ini tidak terdapat pembingkaian pesan untuk memaknai kehidupan sehari-hari., berita dengan judul "Fasha-Maulana Dapatkan Hati hanura" setelah dilakukan pengamatan kata-kata dalam berita tersebut 
tidak terdapat kata yang mempunyai pemaknaan dalam kehidupan sehari-hari dari keseluruhan paragraf, dari lead, tubuh berita hingga penutup.

2. "Breaking News PKS Resmi Dukung Sy Fasha"

Pembingkaian pesan untuk memaknai kehidupan sehari-hari judul berita Breaking News! PKS Resmi Dukung Sy Fasha. Kutipan beritanya sebagai berikut: paragraf 4

"[P]KS berharap dukungan ini menjadi triger awal untuk meraih kemenangan di Pilwako. Untuk diketahui, sejumlah parpol memang sudah menyatakan dukungan kepada Sy Fasha.Selain PKS beberapa parpol sudah menyatakan dukungan secara resmi, yakni Golkar, Gerindra dan Hanura. Beberapa parpol lain dikabarkan juga sudah merapat, hanya saja masih menunggu waktu untuk diumumkan". ${ }^{11}$

Di dalam teks berita di atas terdapat pengunaan kata-kata untuk memaknai kehidupan sehari-hari dengan kata seperi berikut "Beberapa parpol lain dikabarkan juga sudah merapat", Makna dari kata merapat adalah beberapa partai partai politik yang lain, selain dari partai PKS dan partai politik yang sudah resmi menyatakan dukungan kepada Syarif Fasha juga sudah mulai menentukan dukunganya kepada Syarif Fasha sebagai calon walikota.

3. "Deklarasi Fasha-Maulana Akan Hadirkan Amien Rais, Ini Tanggapan PAN"

Hasil pengamatan berita Seru Jambi.com terdapat pembingkaian pesan untuk memaknai kehidupan sehari-hari dengan judul berita "Deklarasi FashaMaulana Akan Hadirkan Amien Rais, Ini tanggapan PAN" dalam berita ini tidak terdapat pembingkaian pesan untuk memaknai kehidupan sehari-hari, setelah di amati dari lead, tubuh berita hingga penutup.

Penggunaan Kata-Kata Dalam Pembingkaian Pesan Seru Jambi.com

Ragam bahasa jurnalistik berbeda dengan ragam bahasa ilmiah, bahasa ilmiah cenderung menggunakan aliran strukturalisme bahasa yang rumit, Sedangkan khalayak tidak punya banyak waktu untuk mencerna bahasa secara tekstual, khalayak butuh sesuatu yang praktis dan detail dapat dicerap dengan

11 Seru Jambi.com diakses melalui https://www.serujambi.com/2017/breaking-news-pksresmi-dukung-sy-fasha/ 
kemampuan kognisi dan efeksi mereka dengan bahasa sehari-hari yang akrab dengan khalayak.

1. Penyederhanaan dari Bahasa IImiah kedalam Bahasa Sehari-hari

a. "Fasha-Maulana Dapatkan Hati Hanura"

Dari hasil penggamatan penulis, bagaimana wartawan Seru Jambi.Com menggunakan kata dalam teks berita terdapat penyederhanaan dari bahasa ilmiah kedalam bahasa sehari-hari kutipan beritanya sebagai berikut: Penyederhanaan Bahasa pada paragraf 5 ("...Menurut Fasha, dukungan yang diberikan Hanura, adalah dukungan berdasarkan kehendak dari masyarakat, karena Hanura menerapkan survei sebagai dasar penentuan dukungan..."). ${ }^{12}$

Terlihat dari paragraf diatas ada kata kehendak Penyederhanaan kata kehendak dari kata baku bahasa indonesia yaitu kata keingginan disederhanakan kedalam bahasa sehari-hari yaitu kata kehendak. paragraf 6 juga terdapat penyederhanaan bahasa kutipannya sebagai berikut. ("...Jadi dukungan yang bukan berdasarkan kemauan dari ketua Hanuranya jelas Fasha..."). ${ }^{13}$

Pada paragraf ini sama seperti pada paragraf di atas kata "keinginan" di ubah kedalam bahasa sehari-hari namun dengan versi bahasa sehari-hari yang berbeda dari kata keinginan di ubah menjadi kata kemauan.

b. "Deklarasi Fasha-Maulana Akan Hadirkan Amien Rais, Ini Tanggapan PAN"

Hasil pengamatan berita Seru Jambi.com terdapat pembingkaian pesan untuk memaknai kehidupan sehari-hari dengan judul berita "Deklarasi FashaMaulana Akan Hadirkan Amien Rais, Ini tanggapan PAN", sebagai berikut:

dalam berita ini tidak terdapat penyederhanaan dari bahasa ilmiah kedalam bahasa sehari-hari setelah diamati dari keseluruhan paragraf dari lead, tubuh berita hingga penutup.

12 Seru Jambi.com di akses melalui https://www.serujambi.com/2017/fasha-maulanadapatkan-hati-hanura/

13 Seru Jambi.com di akses melalui https://www.serujambi.com/2017/fasha-maulanadapatkan-hati-hanura/ 
Penggulangan Kata

a. "Fasha-Maulana Dapatkan Hati Hanura"

Penggulangan Kata pada berita dengan judul "Fasha-Maulana Dapatkan Hati Hanura", pada paragraf 5 ("...Menurut Fasha, dukungan yang diberikan Hanura, adalah dukungan berdasarkan kehendak dari masyarakat, karena Hanura menerapkan survei sebagai dasar penentuan dukungan..."), juga terdapat penggulangan kata Pada paragraf 6 ("...Jadi dukungan yang bukan berdasarkan kemauan dari ketua Hanuranya," jelas Fasha..."). ${ }^{14}$

Dari dua paragraf diatas jelas ada penggulangan kata, pada paragraf pertama terdapat kata kehendak dan pada paragraf kedua juga terdapat kata yang sama namun dengan versi yang berbeda yaitu kata kemauan.

b. "Deklarasi Fasha-Maulana Akan Hadirkan Amien Rais"

Penggulangan kata pada berita dengan Judul "Deklarasi Fasha-Maulana Akan Hadirkan Amien Rais".

paragraf 1

"[P]etahana Pilkada Kota Jambi 2018, Fasha-Maulana, pada 9 Desember mendatang akan menyelenggarakan acara deklarasi pasangan di Lapangan Honda, Kawasan Thehok, Kota Jambi. Pada acara deklarasi ini, pihak FashaMaulana akan menghadirkan para tokoh-tokoh nasional partai politik, termasuk Amien Rais, Ketua Dewan Pembina Partai Amanat Nasional (PAN)". ${ }^{15}$

pada paragraf 4 (“...Sebelumnya, Direktur Fasha Center, Rahman mengatakan, dalam acara deklarasi pasangan Fasha-Maulana, selain mengundang artis-artis ibukota untuk hiburan rakyat, juga turut mengundang tokoh-tokoh nasional partai pendukung..."). ${ }^{16}$

Terlihat penggulangan kata "tokoh-tokoh nasional partai" pada kedua paragraf diatas. Paragraf satu "pihak Fasha-Maulana akan menghadirkan para

14 Seru Jambi.com di akses melalui https://www.serujambi.com/2017/fasha-maulanadapatkan-hati-hanura/

15 Seru Jambi.com di akses melalui https://www.serujambi.com/2017/deklarasi-fashamaulana-akan-hadirkan-amien-rais-ini-tanggapan-pan/

16 Seru Jambi.com di akses melalui https://www.serujambi.com/2017/deklarasi-fashamaulana-akan-hadirkan-amien-rais-ini-tanggapan-pan/ 
tokoh-tokoh nasional partai" pada paragraf empat "juga turut mengundang tokoh-tokoh nasional partai pendukung".

Sinonim

a. "Fasha-Maulana Dapatkan Hati Hanura"

Berita dengan judul "Fasha-Maulana Dapatkan Hati Hanura" Sinonim pada paragraf 1 ("...Kini sudah ada tiga partai politik yang resmi mengeluarkan dukungan kepada petahana Sy Fasha dan wakilnya dr Maulana. Setelah sebelumnya Golkar dan PPP, Fasha-Maulana memikat hati partai Hanura..."). ${ }^{17}$

Dalam satu paragraf ini terdapat kata yang sama yaitu "Sy Fasha dan wakilnya dr Maulana" menjadi "Fasha-Maulana", tetapi dalam versi yang berbeda dalam segi penulisan, sebagai strategi untuk menonjolkan gagasan inti berita.

b. “Deklarasi Fasha-maulana Akan Hadirkan Amien Rais, Ini Tanggapan PAN"

Sinonim pada berita dengan judul “Deklarasi Fasha-Maulana Akan Hadirkan Amien Rais, Ini Tanggapan PAN", pargraf 1 ("...Pada acara deklarasi ini, pihak Fasha-Maulana akan menghadirkan para tokoh-tokoh nasional partai politik, termasuk Amien Rais, Ketua Dewan Pembina Partai Amanat Nasional (PAN)..."), paragraf 4 ("...Sebelumnya, Direktur Fasha Center, Rahman mengatakan, dalam acara deklarasi pasangan Fasha-Maulana, selain mengundang artis-artis ibukota untuk hiburan rakyat, juga turut mengundang tokoh-tokoh nasional partai pendukung..."). ${ }^{18}$

Terlihat pada dua pargraf diatas terdapat sinonim (kesamaan kata) "mengundang tokoh-tokoh nasional partai".Paragraf satu "Fasha-Maulana akan menghadirkan para tokoh-tokoh nasional partai politik" paragraf empat diakhir paragraf "juga turut mengundang tokoh-tokoh nasional partai pendukung".

17 Seru Jambi.com di akses melalui https://www.serujambi.com/2017/fasha-maulanadapatkan-hati-hanura/

18 Seru Jambi.com di akses melalui https://www.serujambi.com/2017/deklarasi-fashamaulana-akan-hadirkan-amien-rais-ini-tanggapan-pan/ 
Kesamaan Topik

a. "Fasha-Maulana Dapatkan Hati Hanura"

Kesamaan Topik pada berita dengan judul "Fasha-Maulana Dapatkan Hati Hanura” paragraf 2 ("...Kamis (2/11/2017) sekitar pukul 19.00 WIB, DPC Hanura Kota Jambi resmi menyerahkan dukungan tertulisnya kepada Fasha-Maulana.", paragraf 4 ("...Hanurayang telah menyerahkan dukungannya kepada kami pasangan Calon Walikota dan Wakil walikota yakni Fasha Maulana,kita ucapkan syukur alhamdullilah kepada Allah SWT..."). ${ }^{19}$

Dari paragraf berita di atas terlihat kesamaan topik, pada paragraf pertama menjelaskan partai Hanura Kota Jambi menyerahkan dukungannya kepada Fasha-Maulana, dan pada paragraf kedua juga terdapat penjelasan partai Hanura telah menyatakan dukungannya kepada Fasha-maulana.

b. “Deklarasi Fasha-Maulana Akan Hadirkan Amien Rais, Ini Tanggapan PAN"

Kesamaan topik pada berita paragraf 1 ("...Pada acara deklarasi ini, pihak Fasha-Maulana akan menghadirkan para tokoh-tokoh nasional partai politik ,termasuk Amien Rais, Ketua Dewan Pembina Partai Amanat Nasional (PAN)..."), paragraf 4 (“...Sebelumnya, Direktur Fasha Center, Rahman mengatakan, dalam acara deklarasi pasangan Fasha-Maulana, selain mengundang artis-artis ibukota untuk hiburan rakyat, juga turut mengundang tokoh-tokoh nasional partai pendukung..."). ${ }^{20}$

Terlihat pada dua paragraf diatas kesamaan topik kata "menghadirkan para tokoh-tokoh nasional partai" pada paragraf satu dan pada paragraf empat kata "mengundang tokoh-tokoh nasional partai".

19 Seru Jambi.com di akses melalui https://www.serujambi.com/2017/fasha-maulanadapatkan-hati-hanura/

20 Seru Jambi.com di akses melalui https://www.serujambi.com/2017/deklarasi-fashamaulana-akan-hadirkan-amien-rais-ini-tanggapan-pan/ 


\section{E. Objektivitas Pesan di SeruJambi.com}

Objektivitas dalam berita sanggatlah penting, karena berita harus sesuai dengan fakta yang terjadi di lapangan, kesesuaian antara foto, judul,tanggal penerbitan dan isi berita harus selaras. Dalam berita harus memiliki narasumber untuk diwawancarai meski hanya satu narasumber saja, namun jika terdapat beberapa narasumber terkait akan lebih baik guna untuk menunjukkan kekerdibilitasan berita, jika terdapat satu narasumber saja belum terlalu kuat untuk menunjukkan objektivitas suatu berita, meski lazimnya media online menggutamakan kecepatan dalam hal penerbitan, namun harus mengutamakan keobjektivitasan dalam berita akan sanggatlah penting demi menjaga kepercayaan pembaca pada suatu media agar menjadi media terpercaya dalam masa yang akan datang. Objektivitas seru Jambi.com adalah sebagai berikut: Laporan "Fasha-Maulana Dapatkan Hati Hanura"

Dari hasil pengamatan penulis, Objektivitas berita dengan judul berita "Fasha-Maulana Dapatkan Hati Hanura" sebagai berikut:

Untuk objektivitas antara foto dan berita sudah sesuai di dalam berita ini menjelaskan bahwa Fasha menerima SK dukunggan dari partai hanura dijelaskan dengan foto Syarif Fasha memegang dokumen sebagai bukti dukungan tertulis dari partai hanura, terlihat di dalam foto beberapa anggota partai hanura juga ikut berfoto saat ditemui wartawan. Dalam berita ini juga terdapat kutipan dari hasil wawancara terhadap nara sumber yaitu, kutipanya sebagai berikut pada paragraf 4 ("...Hanura yang telah menyerahkan dukungannya kepada kami pasangan Calon Walikota dan Wakil walikota yakni Fasha Maulana, kita ucapkan syukur alhamdullilah kepada Allah SWT ujar Fasha..."). ${ }^{21}$

Pada bagian Judul dan isi sudah sesuai.Akan tetapi hanya terdapat satu narasumber saja di dalam berita ini yang di wawancarai seharusnya untuk memperkuat berita harus dari beberapa sumber terkait seperti anggota partai

21 Seru Jambi.com di akses melalui https://www.serujambi.com/2017/fasha-maulanadapatkan-hati-hanura/ 
untuk di wawancarai. Untuk tanggal sudah sesuai dibuktikan wartawan saat peliputan pada tanggal $(2 / 11 / 17)$ berita dimuat pada tanggal $(3 / 11 / 2017)$.

\section{F. Penutup}

Berdasarkan uraian diatas, dapat dilihat ada beberapa aspek yang ditonjolkan oleh Seru Jambi.com dalam pembingkaian pesan yaitu menonjolkan berita pencalonan walikota Syarif Fasha, terlihat tidak keberimbangan/independensi SeruJambi.com dalam mengkonstruksi berita politik. SeruJambi.com cenderung memberitakan Syarif Fasha sebagai salah satu calon kandidat walikota Jambi mendatang. Dari segi penulisan berita terdapat kemampuan wartawan dalam memaknai kehidupan sehari-hari meski tidak terdapat secara keseluruhan di setiap berita yang terbit, ini sebagai salah satu strategi pembingkaian untuk menarik minat baca bagi publik terdapat tatanan permainan bahasa, agenda media Seru Jambi mempengaruhi kahalayak terhadap berita politik Syarif Fasha.

Pada berita terdapat pengunaan kata-kata penyederhanaan dari bahasa ilmiah kedalam bahasa sehari-hari yang bisa dicerna oleh khalayak, seperti kata keinginan disederhanakan mejadi kemauan, kehendak dan sebagainya, pengulangan kata antara paragraf juga terdapat dalam berita-berita yang telah di amati oleh penulis, ini sebagai aspek penonjolan gagasan inti berita yang di sampaikan kepada khalayak, sinonim (kesamaan kata), juga terdapat dalam berita meski dalam penulisan kata yang berbeda namun arti kata tetap sama. Kesamaan Topik, pada berita Seru Jambi.com juga terdapat pada satu paragraf yang penulisan nya hampir sama dengan paragraf yang lain. Secara keseluruhan, penyederhanaan dari bahasa ilmah kedalam bahasa sehari-hari, pengulangan kata, sinonim, kesamaan Topik, adalah sebagian strategi dalam pembingkain berita dalam menonjolkan gagasan inti untuk mempermudah khalayak mencerna/memahami suatu berita dalam proses internalisasi (pemahaman/penapsiran). 
Objektivitas Seru Jambi.com dalam penulisan sudah objektiv, namun ada sedikit ketidaksesuain berita dan foto, ada foto berita hanya terdapat ilustrasi gambar saja dan foto ilustrasi itu terdapat juga di berita yag lain. begitu juga dengan foto, ada foto berita satu sama dengan berita yang lain, ada juga beberapa berita hasil kutipan wawancara hanya terdapat satu narasumber saja, biasanya untuk memperkuat suatu berita bisa saja dari beberapa narasumber. Jika itu dalam hal politik, seperti, akedemisi, pengamat politik dan anggota partai politik untuk diwawancarai, selain narasumber utama dalam berita. gunanya untuk menunjukan kekredibilitas berita yang lebih kuat. Tetapi sebagian berita sudah menunjukkan beberapa narasumber terkait, mungkin dikarenakan lazimnya media online dituntut dalam kecepatan penyampain berita.

Dengan melihat hasil penelitian penulis menyarankan bahwa agar Seru Jambi.com bisa lebih meningkatkan objektivitas dalam pembingkaian berita politik serta tidak berpihak kepada salah satu calon kandidat saja atau suatu kepentingan kelompok tertentu, perlu diketahui bahwa momentum pemilukada dapat ditunggangi oleh kepentingan politis, yaitu bagaimana strategi calon kandidat mencari eksistensi melalui berita politik di media online seperti yang telah di lakukan Seru Jambi.com kecenderungan dalam pemberitaan Syarif Fasha apalagi jika menyangkut kepentingan ekonomi, money politik itu sangat tidak disarankan bagi suatu lembaga seperti media. Karena media merupakan wadah penyampaian seluruh informasi tidak hanya untuk kepentingan kelompok tertentu. di hadapan masyarakat media adalah pengenengah, tidak berpihak kemanapun.

\section{Daftar Pustaka}

Beni Ahmad Saebani dan Afifudin, Metode Penelitian Kualitatif, Bandung: Pustaka Setia, 2009.

Cangara, Hafid, Komunikasi politik: konsep, teori, dan strategi, Jakarta: Rajawali Pers, 2009. 
Effendy Onong Uchjana, IImu Komunikasi Teori dan Praktik, Bandung: Remaja Rosdakarya, 2013.

Gaffar Afan, Politik Indonesia, Transisi Menuju Demokrasi, Yogyakarta: Pustaka Pelajar, 2005.

Nimmo Dan, Komunikasi politik khalayak dan efek, Bandung: Remaja Rosdakarya, 2010.

Nuruddin, Pengantar komunikasi massa, Jakarta: Raja grafindopersada, 2004.

S.Alexander,ed Ralph, Marketing Definition, American Marketing Association, chicago, 1965.

Seru Jambi.com di akses melalui laman https://www.serujambi.com/2017/fashaberharap-peran-aktif-kader-partai-pendukung/

Seru Jambi.com di akses melalui laman https://www.serujambi.com/2017/fashafahrori-versus-zola-sani/

Seru Jambi.com di akses melalui laman https://www.serujambi.com/2017/zolasantai-fachrori-sebut-fasha-adik-nya/

Seru Jambi.com di akses melalui laman

https://www.serujambi.com/2017/breaking-news-pks-resmi-dukung-syfasha/

Seru Jambi.com di akses melalui laman https://www.serujambi.com/2017/fashamaulana-dapatkan-hati-hanura/

Seru Jambi.com di akses melalui laman https://www.serujambi.com/2017/9desember-fasha-maulana-helat-deklarasi-pasangan/

Seru Jambi.com di akses melalui laman

https://www.serujambi.com/2017/deklarasi-fasha-maulana-akan-

hadirkan-amien-rais-ini-tanggapan-pan/

Seru Jambi.com di akses melalui laman https://www.serujambi.com/2017/jikamemenangkan-pilkada-ini-permintaan-pkb-kepada-fasha-mualana/

Sumandria Haris, Jurnalistik Indonesia: Menulis Berita dan Feature Panduan praktis Jurnalistik Propesional. Bandung: Simbiosa Rekatama Media, 2014.

Tamburaka Apriadi, Agenda Setting Media Massa,Jakarta: PT Rajagrafindo Persada, 2012. 